\title{
JUSTIFICATIVAS DA IGREJA CATÓLICA PARA O ESCRAVAGISMO: NO BRASIL COLÔNIA
}

\author{
THE JUSTIFICATIONS OF THE CATHOLIC CHURCH FOR SLAVERY: IN BRAZIL \\ COLONIA
}

\section{Lediane Pereira Ramos ${ }^{1}$}

RESUMO: Esta pesquisa bibliográfica, realizada através de fontes retiradas de artigos, livros, documentos da época colonial no país, vem debater acerca da relação direta da Igreja Católica do Brasil Colônia com o regime escravocrata dos africanos presentes naquela época, onde há de se demonstrar algumas justificativas bíblicas dadas pelos religiosos da época para que houvesse a permissão religiosa, o apoio financeiro e o incentivo por parte da mesma para que se mantivesse o tráfico e o trabalho escravo por quase quatro séculos em solo brasileiro. Objetivando demonstrar quais foram as suas contribuições para que o regime de escravidão brasileira alcançasse tais patamares no que se referiu ao contexto de escravização de homens, mulheres e crianças.

Palavras-chave: Igreja Católica. Escravidão. justificativas.

ABSTRACT: This bibliographical research, carried out through sources taken from articles, books, documents period in the colonial period in the country, discusses the direct relationship of the Catholic Church of Brazil Colony with the slavery regime of Africans presente at that time, where some justifications must be demonstrated. Bibles given bu the religious of the time so that there was religious permission, financial support and encouragement on the part of the same so that trafficking and slave labor could be maintained four centuries on Brazilian soil. Aiming to demonstrate what their contributions were for the Brazilian slavery regime to reach such levels with regard to the contexto of enslavement of men, women and children.

Keywords: Catholic Church. Slavery. justifications.

\footnotetext{
I Licenciatura plena em história/unemat Graduada em Licenciatura Plena em História pela Universidade do Estado de Mato Grosso (UNEMAT, 2018). Professora efetiva na Secretaria de Estado e Educação de Mato Grosso (SEDUC) desde 2018, atuando na Educação Básica no Ensino Fundamental e Médio. Possuo experiência em docência atuando principalmente na Educação de Jovens e Adultos. Ex-bolsista do CNPQ no Programa Institucional de Bolsas Iniciação à Docência da CAPES/UNEMAT (2014-2018). Possuo experiência na Educação Popular e Movimentos Sociais. Especialista em Docência do Ensino Superior e Teologia pela faculdade ÚNICA. Tutora acadêmica. Mestranda em Educação pela Universidade Federal de Rondonópolis - UFRE -mail: leidianemaisa@hotmail.com.
} 


\section{INTRODUÇÃO}

O regime escravocrata esteve presente na humanidade desde os primórdios do surgimento de uma civilização organizada em sociedade, momento em que escravizar o outro, mostrava ser uma relação de domínio sob aqueles que perdiam guerras ou se viam em condição de não conseguir saldar uma dívida, ou até mesmo por questões de pobreza extrema, se viam obrigados a servidão como modo de sobrevivência, então se viam obrigados a submissão do trabalho escravo.

A própria Bíblia relata a relação de servidão como algo comum em várias situações, no Antigo Testamento e também após a vinda do Messias, na remenda judaica, é o rei do reino de Deus na terra, reino de paz e justiça. Os presentes o Messias no fim dos tempos. Os cristãos afirmam que *Jesus de Nazaré é esse Messias esperado. *Cristo. - Do Hebraico "Messias como" = o Ungido (SCHWIKART, 1997, p. 7I), que seria Jesus Cristo que é descrito no Segundo Testamento, e se tornou uma fonte de estudo e uma espécie de "consulta" para os pensadores religiosos numa época em que a ciência ainda estava longe de explicar muitos fatos e eventos relacionados à existência de seres humanos de etnias, classes sociais, religiões e culturas tão distintas entre si. Para explicar a existência de outros povos a partir do século XIII em diante, muitos destes pensadores, pesquisadores e líderes religiosos se baseavam em histórias contadas pela Bíblia, e muitos ainda, não conseguindo compreender tantas diferenças étnicas e não aceitando outra religião a não ser a cristã, começam a escrever inúmeros enredos sobre tais diferenças, sempre pondo a frente seu padrão de vida e sua religião como única, verdadeira e aceitável. Temos aí a forma de dominar mais conhecida da humanidade: o escravagismo humano por acreditar na superioridade intelectual e religiosa. Thorton (2004), descreve bem em sua obra A África e os africanos na formação do mundo atlântico, como o comércio de escravos africanos se fez intenso e único ao longo dos séculos, e como eram tratados os negros, desde a captura em sua terra natal, preços de venda, transportes e falta de uma qualidade de vida, descrevendo os processos de escravidão africana.

E este intenso comercio só se tornara possível por vários outros fatores, como a busca por conquista de território, extração de riquezas naturais, cultivo de terras para inúmeras 
atividades e a propagação do cristianismo, esta última sendo a que financiou os primeiros projetos de colonização, como "Ordem do de Cristo" que foi financiadora das expedições nos primeiros dois séculos no Brasil, onde os jesuítas vinham juntamente com a expedições, a coroa, a cruz e espada eram aliadas neste processo, todos estes ligados entre si com um único propósito maior, e por conta disto, os líderes a frente destes ideais de conquista, a Coroa e a Igreja Católica Apostólica Romana fizeram entre si pactos e acordos que visavam a todo e qualquer preço obterem os melhores resultados, que se baseavam nos lucros financeiros, como Santos (2014,

p. 2I) afirma ao dizer que "o resgate de africanos era justificado pela cristianização e também pela expansão da civilização, tido menos como uma crença e mais como um recurso para o estabelecimento da colonização e da permanência das lavouras". uma nova era da escravidão, movimentando expedições com o único intuito de aprisionar "gente negra", conforme discorre Silva (2011):

No fim do século XVII, ao se falar de escravo, pensava-se em negro. Ficara para trás o tempo em que nas listas da escravaria do sul da Europa tinham destaque árabes, armênios, berberes, búlgaros, circassianos, eslavos, gregos e turcos, e em que os negros eram minoria nas populações escravas das Américas. Quase duzentos anos antes, já se tornara incomum encontrar-se nos espaços dominados pela Europa um escravo branco que tivesse vindo de terras cristãs ou melhor, que fosse europeu. (SILVA, 2011, p. 579)

para servir conforme os brancos acreditavam estar escrito na Sagrada Escritura, e neste meio tempo dariam a essas almas perdidas, segundo a visão do homem branco, a salvação, a vida eterna que foi prometida pelo Senhor, dizendo que seria através da fé cristã, ao serem batizados, pela catequese em massa, que esses homens dantes perdidos, agora teriam a salvação eterna, segundo os pensamentos cristãos da época.

Justificavam-se remontando textos bíblicos, e se sentiam cumprindo um dever moral, social e religioso, pois livravam os negros africanos da sua maldição e castigo por um pecado cometido por seus antepassados, relatos estes descritos na Bíblia e utilizados conforme era conveniente para Igreja Católica e para justificar tais a atrocidades cometidas. Existem algumas teorias da maldição dada por Deus para que os negros pudessem ser escravizados, já que lançou Noé sobre seu filho Cam, uma praga ao qual maldisse, que sua geração futura fosse sujeita a todas as outras gerações do mundo, como servos e escravos, seriam então os africanos essa geração maldita, e deveriam servir para sempre como tal, mais a frente adentraremos nessa maldição com mais detalhes. 
Revista Ibero- Americana de Humanidades, Ciências e Educação- REASE

Estes africanos eram obrigados a aceitarem a nova fé imposta, pois a conversão seria sua única salvação. Podemos observar várias questões para que a escravidão continuasse a ser praticada sem nenhum peso moral, além do apoio e incentivos da Igreja, ainda existiam posições eurocêntricas acerca do assunto, o homem branco descrito como padrão aceitável de ser humano, a cor branca como a cor da pureza em contraponto com o negro, tido como a cor de tudo que não fosse bom, belo ou divino. Entonações múltiplas encontrados pelo homem branco para usar o trabalho escravo e também para pregar sua cultura e sua religião dentre seus escravizados trazidos da África durante o século XVI e XVIII, período do Brasil Colônia.

\section{Escravidão no Brasil}

Escravizar é uma forma de explorar, "no Dicionário Histórico Brasil, Colônia e Império, nos dá uma definição do termo escravo: "o mesmo que cativo, indivíduo que, por ser propriedade do senhor, deveria trabalhar para ele e se sujeitar às suas ordens" (BOTELHO, 2002, p. 69), tendo o ser humano como propriedade, negando-lhe o direito à sua própria sexualidade, religião e cultura, em condições de submissão e servidão que duram até o fim de suas vidas, sem uma alimentação adequada, sujeitos a todos os tipos de violência e subjugação sejam morais e/ou físicas, "não houve um escravismo na história dos homens, mas vários escravismos" (JARDIM, 2007, p. 09. Assim eram tratados os escravos negros africanos, "de fornecedor de ouro, marfim, âmbar, cera, gomas e madeiras corantes e de possível freguês para manufaturas europeias, o africano não demorou em ser visto sobretudo como escravo". (SILVA, 2011, p. 582), que tiveram suas vidas negociadas e traficadas por toda a América por quase quatro séculos como mercadoria não perecível, como descreveu Lovejoy (2002) ao definir a escravidão:

\footnotetext{
A escravidão era uma forma de exploração. Suas características específicas incluíam a ideia de que os escravos eram uma propriedade; que eles eram estrangeiros, alienados pela origem ou dos quais, por sanções judiciais ou outras, se retirara a herança social que lhes coubera ao nascer; que coerção podia ser usada a vontade; que sua força de trabalho estava á completa disposição de um senhor; que eles não tinham direito a sua própria sexualidade e, por extensão, ás suas próprias capacidades reprodutivas; e que a condição de escravo era herdada, a não ser que fosse tomada alguma medida para modificar essa situação. (LOVEJOY. 2002, p. 30)
} 
Desde o transporte até o fim da vida, as humilhações e subjugações eram as mais variadas e constantes, trazidos para sustentar cada vez mais a mão de obra escrava e assim, a base econômica do Brasil, conforme Jardim (2007, p. 22) "se as práticas escravistas exploração do trabalho e o tráfico - definiram o processo de exploração da América Latina pelos países da Europa central, o Brasil não teve uma história diversa desenhada pelo Estado Português" onde podemos perceber que a história da escravidão aqui teve seus principais momentos forjados pela inserção do escravagismo como a parte constitutiva de sua própria sociedade colonial, que naquele período era a produção de açúcar, tabaco, extração de ouro e

outras riquezas minerais variadas, plantação de algodão e café e sua colheita, fez-se necessário o tráfico de escravos africanos para o Brasil já ao final do século XVI. Foi a partir de 1550 que o tráfico negreiro para o Brasil teve seu incentivo, o que somou segundo pesquisas feitas acerca do assunto, números superiores a io milhões em toda américa e no Brasil quase 4 milhões, como está descrito na obra "Para um História do Negro no Brasil" da Biblioteca Nacional":

O Brasil, em razão de sua dimensão e da ausência de preocupação com a reprodução biológica dos negros, foi o maior importador de escravos das Américas. Estudos recentes estimam em quase io milhões o número de negros transferidos para o Novo Mundo, entre os séculos XV e XIX. Para o Brasil teriam vindo em torno de 3.650.00o. (BIBLIOTECA NACIONAL. I988, p. o9).

Momento em que homens, mulheres e crianças de várias regiões da África eram transportados de forma desumana, amontoados em compartimentos com pouquíssimo espaço, nos porões dos navios negreiros que os traziam. O que nos permite compreender o que passariam os cativos africanos e seus descentes em território brasileiro, por longos séculos onde a única voz que se levantou por muitos anos foi a dos gritos dos negros sendo açoitados pelos capatazes e por seus senhores, pois nenhuma lei impedia este comércio, e a própria religião apoiava financeiramente e moralmente a continuidade de tais ações. Podemos perceber que o escravagismo no Brasil, sofreu transformações próprias se compararmos a outros tempos da antiguidade, onde "o sentido que produz significância à expressão trabalho escravo deve estar sempre associado a um determinado contexto histórico", que no caso do nosso país teve significados particulares, e "falar em escravagismo na antiguidade clássica - Grécia e Roma - é diferente de falar do trabalho escravo do 
momento histórico imediatamente anterior ao fim do tráfico pela Europa ocidental; bem como das formas contemporâneas de trabalho escravo no Brasil”. (JARDIM, 2007, p. o9), já

que na Antiguidade os principais meios de escravizar as pessoas eram através das derrotas militares, conflitos entre tribos rivais onde os vencedores dominavam e escravizavam os vencidos, o não pagamento de dívidas financeiras contraídas, e então, em troca de pouparem sua vida eram obrigados a servidão.

Já no Novo Mundo, vemos que o comércio de escravos se tornou um negócio que gerou fortunas, e capturar africanos para traficá-los, se torna inédito no contexto de escravagismo no mundo, onde podemos ver a política mercantilista que geraria sistemas próprios de arrecadação de impostos. Agora, a cor da pele e culturas diferentes definiriam quem era passível de ser escravizado, e não somente a questão de quem vencia ou perdia as guerras intertribais, quem era devedor e não podia saldar a dívida, agora o africano ganha o cenário como a raça que deveria servir, ser subjugada e domesticada ao modo de vida do homem branco, impelindo nesses povos todo o estilo adotado por eles como correto e justo perante ao Senhor.

Os portugueses e os africanos vinham de lugares totalmente diferentes, e isto implicava em ideais e modos de vida que em nada eram parecidos entre si, desde a alimentação, a cultura, a religião, as vestes, a língua e outras particularidades que cada povo tinha. O homem europeu fez do Novo Mundo, uma extensão de seu país, mesmo que não habitando mais a sua terra natal, ele conseguiu trazer consigo a cultura e a religião presentes no lugar de sua origem, e aqui no Brasil recém colonizado passam a ser o centro de tudo, seja financeiramente quanto socialmente e religiosamente, mantendo sua cultura como o padrão ideal para tudo e de tudo. Já o escravo capturado de sua tribo na África, não lhe era permitido nenhuma espécie de ligação com seu "mundo", ele vinha para cá com o único objetivo de trabalhar para gerar riqueza aos europeus, e nada mais lhe restava a fazer, a não ser aceitar essa nova vida e se adaptar ao trabalho e a crença imposta por este Novo Mundo já desenhado pelos que aqui chegaram para colonizar e fazer do lugar seu lar definitivo, como descrito no artigo da Biblioteca Nacional (1988):

Além de trabalho, obediência e respeito às leis e dispositivos disciplinares, os senhores exigiam dos escravos fidelidade, humildade e aceitação dos valores brancos. Os negros deviam aprender a língua portuguesa e a religião católica, 
único bem moral que recebiam dos brancos. Logo que chegavam ao Brasil, os africanos

eram batizados e recebiam nomes cristãos, sendo em geral perseguida a prática dos cultos africanos. (BIBLIOTECA NACIONAL. I988, p. II)

Aos africanos, cabia-lhes agora, esquecer as relações que antes tinham, sua linhagem, seu posicionamento enquanto homem africano, e aceitar o domínio absoluto dos portugueses, não apenas o físico, mas o intelectual também. É importante percebermos a real intenção, tanto da Coroa quanto da Igreja, pois ambas buscavam quantidade de pessoas, tanto para o trabalho servil, quanto para propagar o cristianismo católico, como discorre Santos (2014):

A presença africana na América portuguesa, entretanto, se estabeleceu de forma maciça na medida em que esta se tornou imprescindível para a administração colonial e por conta das atividades que geravam lucro para a Real Fazenda, escravos e africanos eram mercadorias tributadas nas alfândegas de Sua Majestade. O resgate justificado pela cristianização e pela expansão da civilização continuou ocorrendo ao longo dos séculos, menos como uma crença e mais como um recurso para estabelecimento da colonização e da permanência das lavouras. Ao menos é o que indica a preocupação do governador da Bahia no final do XVI. (SANTOS. 2014, p. 21).

Não havia por parte da grande maioria dos representantes da Igreja, um ideal único e sólido de levar a fé católica e o cristianismo para aqueles que a desconheciam e assim salvar suas almas pagãs perdidas, era mais importante ter quem fizesse o trabalho braçal nas lavouras, na casa grande, nos mosteiros, nas fazendas, e levando em consideração que o tráfico negreiro também foi outra fonte de gerar riqueza para quem o praticava naquele período, conforme Silva (20II) discorre:

Tanto aqui quanto no cálculo das exportações de seres humanos pelo continente africano, estamos diante de estimativas, de aproximações, a partir de dados muitas vezes insuficientes e fragmentários. Mas ainda que possamos duvidar da possibilidade de virmos algum dia a obter os números reais do tráfico para cada século, sabemos que o mercadejo de escravos se estava revelando um grande negócio para os europeus, no decorrer do século Seiscentos. (SILVA, 2001, p. 590).

A exportação de escravos superou em valores as de ouro da África Ocidental, no fim do século XVII, números que reafirmam o crescente negócio que era o tráfico de africanos. E estes escravizados, sejam eles em nome da Coroa ou da Igreja, deram seu suor, seu sangue e sua vida para realizar o que pretendiam ambas instituições por séculos no país.

\section{A aliança entre a igreja e a coroa}


As propostas de escravidão ganham força e o apoio da Igreja quando a Santa Sé, que pertencia a Igreja Católica, garantiu através das bulas papais a Portugal o direito de tomar

posse dos territórios africanos. O papa Clemente V, criou a "Ordem dos templários" fundada em Jerusalém, que tinha por objetivo dar proteção aos peregrinos cristãos na Terra Santa reunindo os monges-soldados para as primeiras cruzadas em III9, sendo esta ordem considerada o banco dos papas e sua riqueza era tida como enorme naquela época, e foi durante seu reinado em Portugal, que Dom Dinis (I279-1325), aproveitou a ordem para criar a "Ordem de Cristo" (Ordem do Nosso Senhor Jesus Cristo) em 1319 e que foi proclamada pela Bula Ad ae exquibus pelo Papa João XXII. Esta que passaria a ser a versão de Portugal para a agora extinta "Ordem dos Templários" que por conta de várias acusações de heresias, crimes e de corrupção, onde o Papa Clemente V a dissolve em I3ı2.

E graças aos fundos arrecadados através da ordem, foi que Portugal pode então manter os projetos de colonização pelo mundo a fora, dentre eles, o que por fim seria a do Brasil, e foi também esta ordem, que manteve por dois séculos a missão dos jesuítas em solo brasileiro, conforme Fluck (1991):

É a Ordem de Cristo que foi concedido o direito de jurisdição espiritual sobre as ilhas do Atlântico, bem como a costa da África, até a Índia, na Ásia. A Ordem de Cristo foi, portanto, no caso português, o elemento que possibilitou a união entre fé e império, visto que o rei a presidia. As colônias portuguesas são, portanto, patrimônio da mesma". (FLUCK, 1991, p.151).

Esta aliança entre fé e império, fez com que as colonizações passassem a ter um caráter divino para justificar quaisquer ações que fossem tomadas a partir de então. Comprometendo os monarcas portugueses com a missão de evangelizar as novas terras através do Padroado nas regiões ibéricas levando a bandeira da Igreja católica juntamente com as das esquadras de colonização, e isto trazia ao reino português uma sensação de legitimidade divina enquanto representantes de Deus nos novos espaços de conquista.

De 1500 a 1822 no Brasil, a Igreja católica implementou ações com a proposta de promover a fé cristã na colônia. Sabemos que o negro foi impedido pela escravidão que era submetido a constituir família, manter seus costumes, suas crenças e toda sua cultura que o definia como homem africano, deixando uma única alternativa, a servidão e a religião forçada. A ligação da Igreja com a Coroa portuguesa fortaleceu essas ações, assim como destacou Silva (1990, p. 73), descreve que os teólogos portugueses daquele período 
pensavam sobre a escravidão africana, "todavia, a ideia estava lançada em Portugal e até os teólogos

discutiam a ideia, asseverando uns que a escravidão era lícita, pois que os selvagens seriam chamados, através dela, à fé cristã, já pelo batismo, já pela catequese em massa”.

O que para a Igreja era então uma "Boa Nova” e uma forma rápida de trazer mais fiéis, para a Coroa um negócio e tanto, para os negros era o início de uma vida miserável e cruel, de torturas, submissões e humilhações, totalmente protegida pelas leis morais e religiosas da época, onde as mesmas trabalhavam em comum acordo para o crescimento deste comércio vultuoso. Foram emitidas várias Bulas Papais permitindo e incentivando a escravidão de africanos, podemos destacar duas importantes: a Dum Diversas em 18 de junho de 1452, com caráter geográfico ilimitado, pelo então Papa Nicolau V, onde ele se dirigia ao

Rei Afonso V de Portugal, onde a Igreja como instituição maior, permitia aos portugueses a conquista de territórios ainda não cristianizados, a escravizar os que fossem capturados: os pagãos e os sarracenos. A Bula teria como objetivo final, a conversão dos mulçumanos e dos pagãos escravizados. Ela trazia consigo, a ideia de que os povos eram constituídos de pessoas pagãs, e de seres inferiores espiritualmente, algo que para o pensamento cristão era aceitável, pois na tradição hebraica, a escravidão era algo que o senhor permitia, como se fosse uma forma de castigar os pecados que esses povos cometiam.

Outra Bula foi a Romanus Pontifex, logo concedida também pelo Papa Nicolau V de o8 de janeiro de 1454 , que permitiu ao rei e o infante D. Afonso V e D. Henrique e todos os reis de Portugal e os que os sucedessem a conquista da África e suas regiões, para edificar igrejas e dominar estes territórios como espaços cristãos, declarando-os como pertencentes a Igreja católica, permitindo a concessão do comércio de negros pelos portugueses, como descrito no item $4^{\circ}$ da Bula:

4- Por isso nós, tudo pensando com devida ponderação, por outras cartas nossas concedemos ao dito rei Afonso a plena e livre faculdade, dentre outras, de invadir, conquistar e subjugar quaisquer sarracenos e pagãos, inimigos de Cristo, suas terras e bens, a todos reduzir à servidão e tudo aplicar em utilidade própria e dos seus descendentes. Por esta mesma faculdade, o mesmo D. Afonso ou, por sua autoridade, o Infante legitimamente adquiriu mares e terras, sem que até aqui ninguém sem sua permissão neles se intrometesse, o mesmo devendo suceder a 
seus sucessores. E para que a obra mais ardentemente possa prosseguir. (PAPA NICOLAU V, 8 de janeiro de i454, s.p.).

Nestas duas principais Bulas, que tratam da permissão para evangelizar lugares considerados por eles habitado por incrédulos e inimigos de Cristo, reduzindo todos os seus habitantes a escravidão perpétua física e religiosa. Sem qualquer ressalva, a Igreja Católica, tem neste caso, o direito de permitir e conceder autorização para agir com as forças necessárias para que tais objetivos sejam alcançados, sejam elas ações passivas ou agressivas, deixando bem claro que o que importa mesmo é levar a fé cristã a todo custo e a todos os lugares. Podemos perceber então, como se deram essas conquistas nada amigáveis, e aqui estes povos se tornaram africanos, e passaram a ser identificados como: negros, escravos,

pagãos, sendo considerados inferiores, e vivenciando as faces mais cruéis do racismo e da humilhação.

\section{A posição da Igreja Católica perante o regime escravocrata}

Como único sistema religioso daquele período no Brasil Colônia, a Igreja Católica se auto intitulava a detentora de uma verdade única e absoluta, e ainda reforçavam a ideia que ao batizar o africano, estariam salvando sua alma, através deste sacramento, que era muitas vezes realizado nas praias da África antes do embarque para o Brasil, onde "muitos escravos eram sumariamente, ao serem capturados, já batizados na África ou, imediatamente, nos portos brasileiros, antes de serem vendidos e levados para os engenhos de açúcar" e esse primeiro contato com o cristianismo para o africano já era algo desumano, ao queimar sua pele para ser marcado como animal de criação doméstica, ali ele conhecia a religião do homem branco, o que causava uma primeira impressão nada agradável ou admirável, ainda como descrito "Dom João II ordenou que os escravos fossem marcados a ferro-quente com o símbolo da coroa portuguesa, como prova de que o imposto real já havia sido pago na África. Essa mesma marca servia também como certificado do batismo cristão" (VASCONCELOS, 2005 p. 4I). Que posteriormente, Dom João IV substituiria a marca de ferro por uma argola pendurada no pescoço que continha o mesmo significado de marcação religiosa. A Igreja pregava que a escravidão era necessária, pois para o funcionamento da sociedade ocorrer de forma natural, o criador havia feito os 
africanos para trabalharem como escravos, a fim de passarem suas vidas inteiras na servidão ao homem branco.

Declaravam justa a escravidão, como algo necessário para a humanidade, dizendo assim, que sua prática poderia ter um efeito de salvação, e com esse argumento, abordava de forma aberta e clara tais visões. Os líderes pautados em versículos escolhidos por eles, sem mostrar o contexto e a história bíblica em si, lembrando ainda que o acesso à leitura e a Bíblia nesse período eram somente pelos religiosos da Igreja e os membros da Coroa, os mais humildes e pobres não tinham acesso a leitura e pouquíssimos sabiam ler e interpretar os textos com facilidade, e isso foi uma grande vantagem, pois assim, a Igreja pode justificar-se na palavra sagrada (a Bíblia) suas ações, o apoio à escravidão e o uso dela também, e que "durante o período da escravatura, todas ordens religiosas tiveram escravos no Brasil e se aproveitaram da sua força de trabalho” (PACHECO. 1969, p. 639), demonstrando que a própria usufruiu da mão de obra escrava, como o Frei Caetano próprio, "só para citar um

exemplo: em I878 no Maranhão frei Caetano de S. Rita Serejo, Provincial dos Carmelitas, administrava um patrimônio de mais de 400 escravos”.

Por serem donos de inúmeras propriedades, entre fazendas, casas e tantos outros imóveis, os representantes da Igreja precisavam de funcionários para manter o funcionamento, cultivar as lavouras e tantas outras funções que se faziam necessárias, e usavam os escravos para tais necessidades, só fomentando o escravagismo ainda mais, e sempre com o ideal de que estavam lhes fazendo um bem sem tamanho, pois em contrapartida lhes davam o direito de conhecer a palavra de Deus através da catequese e serem salvos, livrando suas pobres almas da perdição eterna.

Como gratidão, esse escravo era ensinado que obedecer era o melhor caminho, e que deviam aceitar seu destino, pois não havia outra escolha para suas pobres vidas. $\mathrm{O}$ batismo e a catequese eram a promessa de estarem salvos, já que antes do sacramento do batismo, segundo o pensamento daquele período os africanos estavam em pacto com o próprio demônio, como discorre Vasconcelos (2005):

Milhões de homens e mulheres foram barbaramente escravizados $e$ sumariamente introduzidos no cristianismo e no projeto colonial europeu. Por meio da catequese e do batismo cristão, foram obrigados a abandonar cultura e religião ancestrais e a "converterem-se" ao cristianismo. Salvo raras exceções, ela foi conivente com a escravidão, ao ser utilizar ela própria da mão-de-obra escrava para a sua sustentação econômica e ter também servido de base ideológica para a justificação religiosa da escravidão. (VASCONCELOS. 2005. p. 35-36). 
O sistema de aceitação do regime escravocrata foi amplamente usado para benefícios próprios pelo corpo da Igreja, seu reconhecimento frente a escravidão foi algo tão visível e comum, impuseram para o africano a aceitação da nova condição de vida, agora batizados como cristãos, deviam decorar as orações, todos os ensinamentos religiosos católicos, caso não o fizessem eram castigados severamente para que tivessem medo e não se esquecessem de todas as doutrinas religiosas, "salvo raras exceções, não se discute a legitimidade da escravidão negra, ela é aceita como legal." (VASCONCELOS 2005, p. 42). Assim, os escravos eram induzidos a acreditar que a vida de sofrimentos, torturas, castigos e tantas

outras formas de humilhações, era a sua melhor alternativa, e assim sendo, deveriam ser eternamente gratos ao catolicismo e ao seu dono, que permitiam a eles tal "glória".

Em um sermão pregado aos pretos de uma Irmandade do Rosário em i633, Antônio Vieira fala dessa "gratidão", conforme descrito:

E Vieira repreendeu com dureza os senhores e lhes reservou, aos incorrigíveis, o inferno. Para o grande orador, o escravismo nascia da violência e era uma perversão moral. Todavia, como quase todos aqueles que se colocaram, naquela época, ao lado dos que a sofriam, Vieira não advogou a extinção da escravatura. Não apenas por ser sancionada pelo direito e aceita pelo papado, mas porque poucos dentre eles eram capazes de imaginar o funcionamento da sociedade, nas Américas, sem escravos. (SANTOS, 2007, p. 582-583)

Assim os negros deveriam ter a respeito de sua condição de escravo atual "Oh, se a gente preta tirada das brenhas de sua Etiópia, e passada ao Brasil, conhecera bem quanto deve a Deus, e a sua Santíssima Mãe por este que pode parecer desterro, cativeiro e desgraça, e não é senão milagre, e grande milagre!” (VIEIRA. 1954, p. 26-27). Os líderes religiosos ensinavam que a obediência devia ser uma "obrigação de livre arbítrio" para os negros, e que ser cristão para eles era uma prova de que aceitavam Deus e a Igreja Católica como sua única religião, e assim, mesmo vivendo em regime de escravidão teriam a salvação e a vida eterna, não estaria indo contra os ensinamentos bíblicos e contra o próprio Deus, segundo a visão dos seus representantes da época.

Foram assim por vários séculos, defendendo sempre, não apenas a questão da evangelização dos povos que desconheciam a Bíblia e as doutrinas católicas, mas também o desenvolvimento da colônia, ensinando aos negros a aceitação 
Revista Ibero- Americana de Humanidades, Ciências e Educação- REASE

pacífica da sua condição de vida que lhes fora imposta. $\mathrm{Na}$ teoria que sua salvação estava garantida através daquilo que lhes ensinavam, e que após a sua morte todos teriam descanso na glória do altíssimo, pois a servidão e a crença no cristianismo na terra era a prova de obediência que lhes seria cobrado por Deus, o que foi colocado em prática pelos religiosos, com ou sem consentimento dos escravizados.

\section{As justificativas na bíblia}

Haviam várias formas para justificar o escravagismo, pois até "o pensamento europeu da época alimentava-se da bíblia, na doutrina da Igreja e na antiguidade greco-romana" onde "Nos Antigo e Novo Testamentos, a escravidão aparece como um fato

natural: não é justificada nem condenada" (SILVA, 20II, p. 584). Ainda como discorre Silva (2011):

Doutores da Igreja, e dos mais ilustres, procuraram explicar e justificar a escravidão. Santo Agostinho tinha-a como consequência do pecado - não havia escravo que não merecesse ser escravo - e a inscrevia no grande esquema ordenado do mundo. Santo Isidoro de Sevilha iria mais longe: a escravidão tinha origem divina e se destinava a resgatar o cativo de sua perversidade genética. Já para Santo Tomás de Aquino, que teorizou demoradamente sobre a escravidão, ela, embora

dolorosa, era útil e necessária ao cumprimento dos propósitos na natureza (SILVA, 20II, p. 584).

Dentre as justificativas pautadas pela Igreja Católica Apostólica naquele período, foi que, enquanto o cristianismo se propagava pela costa da África quando houveram as primeiras Grandes Navegações, e a religião nativa era contrária aos princípios cristãos, a grande maioria não aceitou o Evangelho pregado pelo catolicismo, além da religião Islâmica já estar propagada e por também não aceitarem os princípios católicos, a Igreja então adotou

uma postura frente a tais problemáticas, usando a bíblia e seu conteúdo para afirmar que os negros africanos, eram descendentes de Cam e de Canaã, personagens bíblicos, filho e neto de Noé, que foram amaldiçoados por ele.

Cam zombou da nudez de Nóe, quando jazia embriagado e desacordado após provar o fruto da própria videira, tendo ele visto a nudez do pai, em vez de levá-lo para um local reservado e cobri-lo, Cam foi chamar seu filho Canaã e seus irmãos, no trecho encontrado 
na Bíblia (2014), no livro de Genesis, no Antigo testamento vemos a narrativa deste evento:

20 Sendo Noé lavrador, passou a plantar uma vinha 2i Bebendo do vinho, embriagou-se e se pôs nu dentro de sua tenda. 22 Cam, pai de Canaã, vendo a nudez do pai, fê-lo saber fora, a seus dois irmãos. 23 Então, Sem e Jafé tomaram uma capa, puseram-na sobre os próprios ombros de ambos e, andando de costas, rostos desviados, cobriram a nudez do pai, sem que a vissem.24 Despertando Noé do seu vinho, soube que lhe fizera o filho mais moço 25 e disse; Maldito seja Canaã; seja servo dos servos a seus irmãos (BÍBLIA, 2014, livro: GÊNESIS. Capítulo:9, Versículos 20-25, p. 8).

Então, quando acorda, Nóe profere uma maldição, "observa-se que a descendência de Cam originou os povos africanos, ameríndios e parte dos asiáticos e da Oceania. Nesse momento, é fundamental recuperarmos a maldição que Nóe proferiu contra Canaã: 'Maldito seja Canaã; que seja servo dos servos de seus irmãos'” (ROEDEL, 2020, p. 04), sobre os dois, para que esses fossem escravos dos escravos, e de acordo com a bíblia, Cam foi um dos filhos de Nóe que havia partido para o sudeste da África entre as localidades próximas ao Oriente Médio.

Ainda, com base nessa justificativa, os geógrafos e estudiosos do período que antecederam as navegações ruma as Índias, acreditavam que o mundo era dividido em três partes, sendo Ásia e a África separadas pelo Rio Nilo, onde a África se estendia a ponte do Egito e da Líbia e Etiópia seria várias vezes incluída na Índia, onde o cristianismo ligou essa divisão a preceitos bíblicos, dizendo que Noé havia dividido entre seus filhos essas três regiões, Sem foi habitar a parte oriental desde Mesa a Sefar, Jafet a região setentrional que consiste na Europa e os países da Ásia que estão em volta do Mar Negro e o Mar Cáspio, e por fim, o filho e o neto da maldição foram para a região da África:

E aqui haveis de notar estes negros, posto que sejam Mouros como os outros, são, porém, servos daqueles por antigo costume, o qual creio que seja por seu filho Cam, pela qual maldição que depois do dilúvio lançou Nóe sobre seu filho Cam, pela qual madisse, que a sua geração fosse sujeita a todas outras gerações do mundo, da qual estes descendem. (ZURARA. 1937, p. 85)

Baseada nesta história bíblica, a Igreja manteve por muito tempo a ideia que os povos das regiões da África poderiam ser escravizados, com a premissa de serem descendentes de Cam e Canaã, a geração amaldiçoada por Noé. Os religiosos da época acreditavam que os negros eram povos ignorantes somente pelo fato de desconhecerem a Bíblia e o 
cristianismo, e que seriam seres pagãos, que a salvação era somente pela conversão ao Cristianismo, como reafirma SANTOS (2014):

Os cristãos, naturalmente, faziam esta justificativa remontar ao texto bíblico. A maldição lançada por Noé ao seu filho Cam havia recaído sobre os negros, que seriam seus descendentes, destinando-os a servidão. $O$ cristianismo, portanto, teria um papel civilizador ao resgatá-los da barbárie. Esse mesmo princípio de civilidade dada pela religião justificou a escravidão indígena na América espanhola, através da bula promulgada por Alexandre VI ainda no início do século XVI. (SANTOS. 2014. p. 21).

Ao lhes impor tais ideais e precitos religiosos e morais, ficava impedido aos africanos o direito de seguir suas tradicionais e ancestrais culturas religiosas, ter fé naquilo que de fato acreditavam dantes, como se as torturas sofridas pela vida que agora se obrigavam a ter não fossem castigo suficiente, as crenças e as suas conviç̧ões lhes seriam negadas e silenciadas a todo custo. Assim, a África e seus habitantes eram herdeiros da maldição de Noé segundo o que os religiosos e os pensadores daquele período entendiam, e pautados no seu livro sagrado, ocuparam o espaço geográfico que foi o cenário do comércio intenso de escravos, o maior de todos os tempos. Uma justificativa se baseia em Adão e Eva, conforme Azzi (1987):

A primeira delas afirma que a escravidão era consequência do pecado de Adão, e da maldição divina imposta ao homem de trabalhar a terra "com o suor do rosto... A segunda versão considera os africanos como descendentes de Caim e, portanto, traziam ainda na carne a maldição divina, ao primeiro homicida da humanidade... $\mathrm{Na}$ tradição popular, os negros eram considerados como a raça maldita de Caim, sendo a negritude de sua pele o sinal imposto pelo próprio Deus. (AZZI. 1987, p.8o)

Que a cor dos africanos era fruto do pecado vinha de Adão e Eva cometeram no início da criação do mundo, como está escrito no livro de Gênesis e este foi outro trecho utilizado

pelos representantes da Igreja Católica na época, remontando e criando seus próprios entendimentos particulares de tal passagem, BÍBLIA (2014):

II Perguntou-lhe Deus: Quem te fez saber que estavas nu? Comeste da árvore de que ordenei que não comesses? 12 Então, disse o homem: A mulher que me deste por esposa, ela me deu da árvore, e eu comi. 13 Disse o SENHOR à Deus a mulher: Que é isso que fizeste? Respondeu a mulher: A serpente me enganou, e eu comi. (...) is Porei inimizade entre ti e a mulher, entre a tua descendência e o seu

descendente. Este te ferirá a cabeça e tu lhe ferirás o calcanhar. (BÍBLIA, livro de Gênesis, v: II-I5, 2014, p. 04). 
Revista Ibero- Americana de Humanidades, Ciências e Educação- REASE

Essa desobediência era a causa de a escravidão existir, que era uma maldição de Deus aos homens, e imposta aos africanos para trabalhar na terra com o suor do próprio rosto, pois agora o sofrimento fazia parte de sua existência por conta do pecado original. Outra versão, era que os africanos eram descendentes de Caim, filho de Adão e Eva, o primeiro fratricida da humanidade, e os negros traziam na pele o "sinal" imposto pelo próprio Deus, sinal este, que para alguns religiosos seriam que ele teria se tornado negro e foi o pai dos africanos e assim, amaldiçoados a serem escravos até o fim dos dias na terra, ele por não ter se arrependido em momento algum de ter matado seu irmão, foi lhe dado este castigo.

Ambas as versões descritas, baseadas em pontos comuns as questões que a nação maldita estaria marcada pela cor da pele escura, podendo assim ser facilmente identificada e separada das demais. Nesta perspectiva, eles analisavam a escravidão como algo natural e inerente ao negro, onde o pensamento europeu da época se valeu da Bíblia, nas doutrinas da Igreja, se valendo também na Antiguidade greco-romana, nos textos do Antigo Testamento. Todo aquele ou aquela que fosse negro ou negra, segundo as concepções europeias da época, eram os grupos humanos que carregam a maldição divina, e deviam servir para sempre, pois traziam em sua genética as marcas da sua inferioridade e do seu destino a servidão e a obediência ao homem branco, se submetendo a todas as ordens daquele que o dominasse, como fiel servo, demonstrando sua gratidão e submissão sem nenhuma ressalva.

E dentre outras obrigações para com o homem branco, deviam ser gratos por lhes apresentar sua crença, que segundo eles, era a palavra que os salvaria da estarem perdidos, de serem seres pagãos, e assim, ao se batizar e seguir os preceitos católicos, teria uma nova chance de serem reconhecidos como filhos de Deus.

\section{CONSIDERAÇÕES FINAIS}

Através das pesquisas bibliográficas realizadas, podemos analisar que o escravagismo de africanos a partir do século XVI teve um cenário diferente da escravidão praticada na Antiguidade, estas praticadas desde as mais remotas civilizações humanas, e estes aspectos ganham novos personagens no seu enredo histórico, unindo a Coroa, Igreja 
Revista Ibero- Americana de Humanidades, Ciências e Educação- REASE

Católica Apostólica Romana e o negro como os principais atores desse novo modo de um regime escravocrata.

A escravidão no Brasil colônia era definida pela questão da cor da pele, costumes e crenças diferentes, e se tornam o maior mercado em ascensão neste período, e também o que mais dizimou vidas de homens, mulheres e crianças ao longo de quase quatro séculos. E esses aprisionamentos se justificavam em nome de supostas "salvações". Com o intuito de ter mão de obra barata, o tráfico negreiro em pouco tempo se organizou e conquistou países da Europa e de toda a América, este negócio tão rentável e crescente teve apoio e incentivos maciços da Igreja Católica, que visava atingir os lugares mais longínquos da terra que fossem possíveis de se chegar naquela época, para batizar e contabilizar os novos convertidos ao cristianismo e a fé ao catolicismo, mesmo que essa conversão fosse através da força física. Não houve por parte dos líderes religiosos da época, qualquer tipo de contrariedade frente ao escravagismo de africanos, ou qualquer ação ou medidas abertas e consideráveis para que o tráfico de "gente preta" fosse combatido, muito pelo contrário, houveram medidas sim, tais como as bulas papais e acordos com a Coroa Portuguesa para que se aprisionassem o maior número possível de pessoas, consideradas pela Igreja com seres pagãos, perdidos, e se justificavam assim, para declarar justa a escravidão e apoiá-la, e mais ainda. Os próprios líderes religiosos faziam uso da mão de obra escrava em benefício próprio do trabalho servil dos negros escravizados e convertidos pela força a nova religião do homem branco europeu, em suas propriedades particulares, nos conventos, nas fazendas, em seminários, paróquias e outros locais que eram de posse do clero religioso.

Esses mesmos líderes religiosos, se justificavam através da Bíblia Sagrada, esta que para eles funcionava como um guia de regras e condutas humanas, e por conta disto, usando de versículos bíblicos extraídos de um texto qualquer, que não tinham nada a ver com o conceito de que a escravidão era permitida por Deus, como algo divino e aceitável, e que se alguns seres humanos desconheciam a fé cristã, era por castigo ou maldição divina, e a missão desses líderes religiosos era a conversão do povo pagão sem alma, para que pudessem obter a salvação e a redenção, que segundo a visão católica, só era possível através da conversão ao cristianismo. Com estas prerrogativas religiosas, fez-se do escravagismo, um movimento necessário para a época, e do homem africano, o ser 
merecedor destes crimes físicos, morais, sociais e psicológicos, mostrando ser uma das piores faces do racismo de todos os tempos da história da humanidade.

\section{REFERÊNCIAS}

Bíblia Sagrada. 2ª edição. Barueri-SP: Sociedade Bíblica do Brasil, 2014.

BOTELHO, Ângela Vianna; REIS. Liana Maria. Dicionário histórico Brasil: colônia e império. 3 ed. Belo Horizonte: Autêntica, 2002.

BUENO, Eduardo. Brasil: uma História, a incrível saga de um país. $1^{\underline{a}}$ Edição, $7^{\underline{a}}$ impressão. São Paulo-SP. Ática, 2007.

BUENO, Eduardo. A coroa, a cruz e a espada. (Terra brasilis: 4) Rio de Janeiro. Objetiva, 2006.

JARDIM, Philippe Gomes. Neo-escravidão: As relações de trabalho escravo contemporâneo no Brasil. Universidade Federal do Paraná. Curitiba, 2007.

LOPES, Marília dos Santos. Da descoberta ao saber. Os conhecimentos sobre África na Europa dos séculos XVI e XVII. Viseu: passagem, 2002. p. 125.

LOVEJOY. Paul E. A escravidão na África: uma história de suas transformações. Tradução Regina A. R. Bhering e Luiz Guilherme B. Chaves. Rio de Janeiro: Civilização Brasileira, 2002.

MARQUES, Alfredo Pinheiro. A cartografia dos descobrimentos. Lisboa: Edição Ello, I994.

PACHECO. Felipe Conduru. História Eclesiástica do Maranhão. SENAC, Maranhão I969.

PRANDI, Reginaldo. De Africano a afro-brasileiro: etnia, identidade, religião. REVISTA USP, São Paulo, no 46,p. 52-65, junho/agosto 2000.

PRIORE, Mary Del. Esquecidos por Deus. Monstros no mundo europeu e iberoamericano, uma história dos monstros do Velho e do Novo Mundo (séculos XVI-XVIII) São Paulo: Companhia das letras, 2000.

REIS, João José; SILVA, Eduardo. Negociação e conflito: a resistência negra no Brasil escravista. São Paulo: Companhia das Letras, 2009. 
REVISTA DE HISTÓRIA DA BIBLIOTECA NACIONAL. № ıo8, Gráfica Ediouro, Rio de Janeiro, 2014.

REVISTA DE HISTÓRIA DA BIBLIOTECA NACIONAL. Gráfica Ediouro, Rio de Janeiro. № 81,2012.

SANTANA. Tânia de. O culto a Santos Católicos e a Escravidão Africana na Bahia Colonial. Revista Aulas. Dossiê Religião. Org. Karina K. Bellotti e Mairon Escorsi Valério. № 4, abril de 2007.

SCHAWARTZ STUART. Purgando o Pecado Original. In: Reis, J.J. (org.) Escravidão e Invenção da Liberdade: estudos sobre o negro no Brasil. São Paulo, Brasiliense, 1988.

SCHWIKART. Georg. Dicionário Ilustrado das Religiões. 1997, (tradução Clóvis Bovo). Aparecida-SP. Santuário, 200I.

SILVA. José de Carvalho e. História Geral do Brasil e universal. São Paulo: Iracema Ltda, I990.

SILVA. José de Carvalho e. A manilha e o libambo. A África e a escravidão, de I50o à I7oo. Apresentação: José Reis. 2ª edição. Ed. Nova Fronteira. 2011.

VAINFAS. Ronaldo. Ideologia e escravidão: os letrados e a sociedade escravista no Brasil colonial. Petrópolis: Vozes, 1986. (História Brasileira, 8)

VIEIRA. Antônio. (padre). Obras Escolhidas. 1954. Prefácio e notas de Antônio Sérgio e Hernâni Cidade, vol. XI. Sermões (II), Lisboa, Livraria Sá da Costa.

ZURARA, Gomes Eanes da. Crónica de Guiné. Porto: Livraria Civilização, 1937. p. 85. Web pesquisa:

BULA ROMANUS PONTIFEX. A bacia das almas. Disponível em https://digital.arquivos.pt/details?id=3907977 [Acesso em 20-II-I7]

DESTRO, Letícia. A África $\mathbf{e}$ os africanos nas fabulações cartográficas. https://www.revistanavigator.com.br/navigi3/dossie/ $\mathrm{N}_{13}$ dossie3.pdf [Acesso em 20-102016]

Fé in Dicionário infopédia da Língua Portuguesa com Acordo Ortográfico [em linha]. Porto: Editora, 2003-2017. Disponível na Internet: https://www.infopedia.pt/dicionários/linngua-portuguesa/fé [Acesso em 23-10-2017].

Fé in Dicionário Aurélio de Português Online, publicado em: 2016-09-24, revisado em: 2017-022-2017. Disponível em; https://dicionariodoaurelio.com/fe. [Acesso em: 24-10-2017] 
FLUCK, Marlon Ronald.. Evangelização no Brasil Colônia (Séculos XVI e XVII). Estudo corporativo de Três modelos Missionários. I99I ism.edu.br/periodicos/indez.php/estudos_teologicos/article/download/996/962 [Acesso em 2015-05-23]

In Dicionário Priberam da Língua Portuguesa [em linha], 2008-2013, https://www.priberam.pt/dlpo/religioC3\%A30 [Acesso em 24-I0-2017]

In Dicionário Aurélio de Português Online, publicado em: 2016-09-24, revisado em: 201702-27. Disponível em: https://dicionariodoaurelio.com/religao. [Acesso em: 24-10-2017]

ROEDEL, Hiran. Do mito de Cam ao Racismo Estrutural: Uma Pequena Contribuição ao Debate. Projeto AFRO-PORT: Afrodescendência em Portugal [FCT/PTDCANT/30651/2017]. Lisboa. № 02. Julho. 2020. or-19. Disponível em: https://cesa.rc.iseg.ulisboa.pt/afroport/artigos/ [Acesso em 20-o6-2I] 